Intergovernmental Programs Under President Clinton

Ronald John Hy, University of Arkansas, Little Rock

R. Lawson Veasey, University of Central Arkansas

The Clinton administration was elected with a mandate for change. This essay speculates on the projected impact of Clinton's plans on the intergovernmental relationship. Specifically, the various components of federal support for intergovernmental activity are discussed in relation to Daniel Elazar's classic typology of federal aid. During the campaign and transition phases, Clinton was perceived by some as a "tax and spend" Democrat. The research below contradicts that popular wisdom and suggests the probability of a leaner, more nationally-directed system of aid for subnational authorities. Ultimately, under the Clinton administration the competition for intergovernmental support may prove more fierce than it was in the 1980 s.

The Clinton administration comes to power having made a commitment to spend more money to develop the infrastructure and educational systems in the states. Clinton's New Covenant suggests that the federal government spend more money on domestic programs that the Reagan and Bush administrations shifted administratively to the states without concomitant transfers of fiscal resources. This essay attempts to speculate on the types and extent of the adjustments Clinton intends to make in the intergovernmental arena inherited from Presidents Reagan and Bush.

To accomplish this task, the essay first organizes Clinton's vast array of intergovernmental statements, beliefs and opinions into a conceptual framework in order to understand better the primary focus of his intergovernmental policy positions. Then, some baseline intergovernmental expenditures are estimated in order to measure the impact of Clinton's intergovernmental policies. It will be assumed that intergovernmental expenditures below or above these amounts can be attributed (roughly) to Clinton's intergovernmental policies.

\title{
Typology of Federal Aid
}

Daniel Elazar $(1972,472)$ has classified federal aid as having operated according to three models:

Ronald John Hy is Professor of Public Administration and Senior Research Specialist at the University of Arkansas, Little Rock.

R. LAwSON Veasey is Professor of Political Science and Director of the Public Administration Program at the University of Central Arkansas.

The American Review of Politics, Vol. 14, Summer, 1993: 249-265

(C)1993 The American Review of Politics 
- Federal Government As Servant Model-The federal government raises revenues which it funnels back to state and local governments without specifying how the money is to be used.

- National Uniformity Model-Strict, uniform conditions are attached to the federal funds that are distributed to state and local governments.

- Local Right/National Interest Model-National interests compel the federal government to attach uniform standards to the money it distributes to state and local governments, but at the same time the federal government acknowledges the existence of differing and legitimate state and local needs.

Elazar maintains that the Federal Government As Servant model typified federal aid distribution during the nineteenth century. The Local Right/National Interest type prevailed through much of the twentieth century, and the National Uniformity type has been in vogue since the early 1970s (Veasey 1988, 62). Continued practice of the national uniformity approach is viewed by Elazar as problematical. However, Clinton's intergovernmental policies best fit the national uniformity approach, insofar as he seems to stress the distribution of federal intergovernmental revenues according to stringent federal guidelines.

This claim that President Clinton's intergovernmental philosophy reflects the national uniformity type is supported by examination of his beliefs, opinions, and statements. Over the last 13 years, as Governor of Arkansas and as a member and chair of the Democratic Leadership Council (DLC), he has solidified these beliefs. In rereading his campaign statements, it is quite apparent that some of Clinton's advisors have had a considerable impact on his opinions about the effects of intergovernmental policies. To estimate the direction and magnitude of Clinton's intergovernmental thrust, one must understand the extent to which these advisors helped him map out not only an election strategy, but also a plan of governance.

In the late 1980s, some of Clinton's early advisors, particularly the DLC types, were part of the "New Paradigm Society" founded by James Pinkerton and Elaine Kamarck to explore the possibility of a conservative/ liberal consensus on various domestic programs. This group envisioned intensified government activism that would expand individual choice, empower the poor, and create decentralized, flexible, and adaptable institutions to replace much of the bureaucracy currently stifling Washington. The New Paradigm group argues that technology and global markets are breaking down many of the federal government's centralized structures. 
[Clinton] has, for example, endorsed parental choice among existing public schools but not the ideal of new "charter" schools, which is far more threatening to teachers' unions. (The "public choice" scheme Clinton implemented in Arkansas is especially tepid, requiring students at, say, poor urban schools to obtain the approval of the rich suburban school they want to attend.) Likewise, Clinton endorses "tenant ownership," but cites a program in Tampa that doesn't actually sell off any public housing units. Most conspicuously, Clinton doesn't dare offend public employee unions by talking about contracting government services out to competing private firms (Kaus 1992, 22).

Nevertheless, Clinton's Putting People First: A National Economic Strategy for America, which relies a great deal on New Paradigm thinking, serves as both a basis and a blueprint for estimating the types and extent of his intergovernmental programs. Translated into its simplest terms, it states that government ought to invest in human capital and productive goods. Upgrading the country's infrastructure and skills of workers are held to be the most efficient way to increase productivity and competitiveness. For instance, the plan recommends creating a nationwide system of technical and professional certificates for workers, coupled with incentives for employers to hire those workers and to train other workers for new and highly technical jobs. (Clearly, non-college America is to be a priority.)

The plan, Clinton feels, is far superior to giving tax breaks to individuals and corporations, both of whom could spend those dollars however they see fit without regard for the country's needs. The plan, therefore, is designed to reconstruct America via guided federal spending. Clearly, Clinton believes in the redemptive power of government as a tool for social and economic change - and his proposed intergovernmental programs reflect this belief.

\section{Intergovernmental Overview}

In Putting People First, Clinton reiterates his commitment to a broadbased, national agenda for the revitalization of America by stating, "My strategy puts people first by investing more than $\$ 50$ billion each year over the next four years to put America back to work - the most dramatic economic growth program since World War II (Clinton Campaign 1992, 3). Clearly, the Clinton agenda is similar in many respects to the programs he espoused during his twelve year tenure as Arkansas' governor.

Clinton embraced the national uniformity philosophy of intergovernmentalism when he enunciated the following agenda:

My strategy recognizes that the only way to lay the foundation for renewed American prosperity is to spur both public and private investment. To reclaim our future, we must strive to close both the budget deficit and the investment gap. These investments will create millions of high wage jobs and provide tax relief to working families. They will 
also help move people from welfare to work, provide lifetime learning, and ensure affordable health care for every citizen (Clinton Campaign 1992, 4).

This strategy is comparable to Clinton's experience in Arkansas, where, between 1982 and 1992, he focused on one or two major policy efforts at a time while building up his credibility with the general public and the state legislature.

As Governor of Arkansas, Clinton honed his political skills through experience in the "school of hard knocks." During his first term in office, 1979-1980, Clinton encouraged the legislature to pass a significant highway aid package of $\$ 47$ million, foreshadowing his present commitment to infrastructure development. His enthusiasm for governing was damped somewhat following his espousal in 1979 of a significant increase in the fees for auto license tags and title transfers. The voters of Arkansas rejected Clinton and his proposal to increase auto fees by electing Frank White (R) as governor in 1980. Following a period of self-doubts dispersed by several confidencerestoring tours of the state's grassroots, Clinton regained the governorship in 1982 with a successful campaign strategy predicated in part on public apology for his previous disregard of public sentiment concerning state and local revenue policy. This approach, though openly criticized by political pundits, was accepted as sincere by the voting public, who gave him 55 percent of the vote.

After Governor Clinton's return in 1982, he formulated a public policy strategy reminiscent of Franklin Roosevelt's. Roosevelt, consistent with Machiavelli's advice in The Prince, believed in sponsoring one or two major programs each year so as not to confuse the focus of the administration or of the public.

Similarly, Clinton would endorse one or two broad-based policy concerns every two years to address organic problems facing the state of Arkansas. In so doing, Clinton always focused upon a policy of central significance to the public and to political elites, on which the support of each was virtually automatic, and thus avoided negative feelings such as those caused by the auto fee debacle of his first term in office. Clinton's defeat by White illuminated the path to success for the young governor, which was to shun revenue proposals other than increases of the comparatively popular sales tax.

Several themes stand out during Clinton's decade-plus as governor: (1) emphasis on infrastructure development, beginning in 1979; (2) commitment to quality public education and generation of resources to support it; (3) broad-based initiatives to make Arkansas competitive in the global marketplace, and second to none nationally in the creation of jobs; and, most 
recently, (4) efforts to protect the environment and to conserve natural resources, as personified in the selection of Senator Gore as running-mate.

The aforementioned policy themes provided the bedrock upon which Clinton's meteoric political career has been constructed. Although Clinton's longitudinal consistency of commitment to these issues has worked against him at times, overall, his focus and energy for this agenda has made of him a political figure of prominence, first in Arkansas and then across the country. The two policy areas that have drawn the most praise nationally have been his leadership in reforming the state and local educational apparatus, and his almost religious endeavor to create jobs to develop the economy of Arkansas. If Clinton's Arkansas record is any guide, economic development and education reform could be two early intergovernmental emphases of the Clinton Presidency.

The appointment of Thomas F. "Mack" McLarty as President Clinton's Chief-of-Staff could be construed as a clear indication of the emphasis the President will give to the creation of jobs and the stimulation of the economy. McLarty harbors a strong concern about the deficit situation, as well as the need to address America's competitiveness at home and abroad (McLarty 1992). The drive to stimulate the economy could run afoul of the simultaneous environmental protection and conservation themes, but the administration's commitment to both policies are indicative of the publicprivate partnership notion espoused by the Clinton-Gore team during the campaign.

\section{Intergovernmental Finance}

The vision espoused by the Clinton-Gore campaign promoted a holistic restructuring of the domestic economy. Discussion of the financing of that restructuring was much more narrowly focused on specific spending cuts, entitlement reform, tax fairness, closing corporate loopholes, and limiting new program proposals - all of which would affect intergovernmental programs substantially. These proposals appear to be limited to three "new investment" areas: (1) job creation, (2) rebuilding families and workfare, and (3) enhancing of education and training programs.

Clinton apparently continues to support two critical economic concerns: (1) deficit reduction and (2) stimulation of the economy through job creation. Spending cuts appear to fall disproportionately upon the Department of Defense, the federal civilian workforce, university research, and the Department of Agriculture - none of which drastically would affect intergovernmental expenditures. On the other hand, entitlement reform, tax fairness, and the closing of corporate loopholes all are designed to increase 
revenues from the upper-middle and elite economic classes. Unlike the spending cuts, these proposals, if implemented, definitely would have an impact upon intergovernmental expenditures.

In 1988, IGR expenditures by the federal government were $\$ 115.3$ billion (actual) and will escalate to $\$ 138.1$ billion (estimate) by 1994 . As Table 1 indicates, most of the more than $\$ 115$ billion spent in 1988 went for transportation ( $\$ 18.1$ billion), social services ( $\$ 19.9$ billion), health $(\$ 32.6$ billion), and income security ( $\$ 31.6$ billion). Subsequent budget estimates in Table 1 generally indicate a continuation of major IGR expenditures in those same areas, reflecting the Bush administration's budget priorities (Special Analysis H 1990, H-19). Of the major IGR functions, those most likely to receive budget increases during the Clinton administration are transportation, education, training, employment and social services, health, income security, and natural resources.

\section{Specific IGR Area Analyses}

Transportation. America's infrastructure could be the obvious beneficiary of Clinton's "pump priming" plan to stimulate job creation. Obviously, highway construction could reap much of the $\$ 20$ billion annual expenditure in this area over the next four years. Clinton calls for publicprivate funding of this effort, including the empowerment of pension funds to underwrite construction. The commitment of state and local government dollars, although required, remains unclear as far as amounts and administrative responsibility. Toll roads and user fees, consistent with Clinton's "pay as you go" theme, seem likely.

Community and Regional Development. As part of the "Rebuild America" plan, HUD and the CDBG program will be involved centrally in attacking the country's urban blight, specifically targeting roads, bridges, water and sewage treatment plants and low-income housing. Community development banks, private lenders, and traditional sources of financing will be provided incentives to invest in the restructuring. Construction and renovation jobs should enhance the overall employment picture. Although Clinton plans to provide billions of federal dollars for such infrastructural rebuilding, he indicates that many more dollars will be needed if we are going to address the deficit problem during the same timeframe. Nonetheless, this area will reap many of the benefits of Clinton's job creation effort.

Education. The retraining of America's workforce, similar to the JTPA program, will be the responsibility of not only government, but of employers. This Clinton "imperative" incorporates learning, training, and restructuring the welfare net to enhance family development. The administration 
Intergovernmental Programs under Clinton | 255

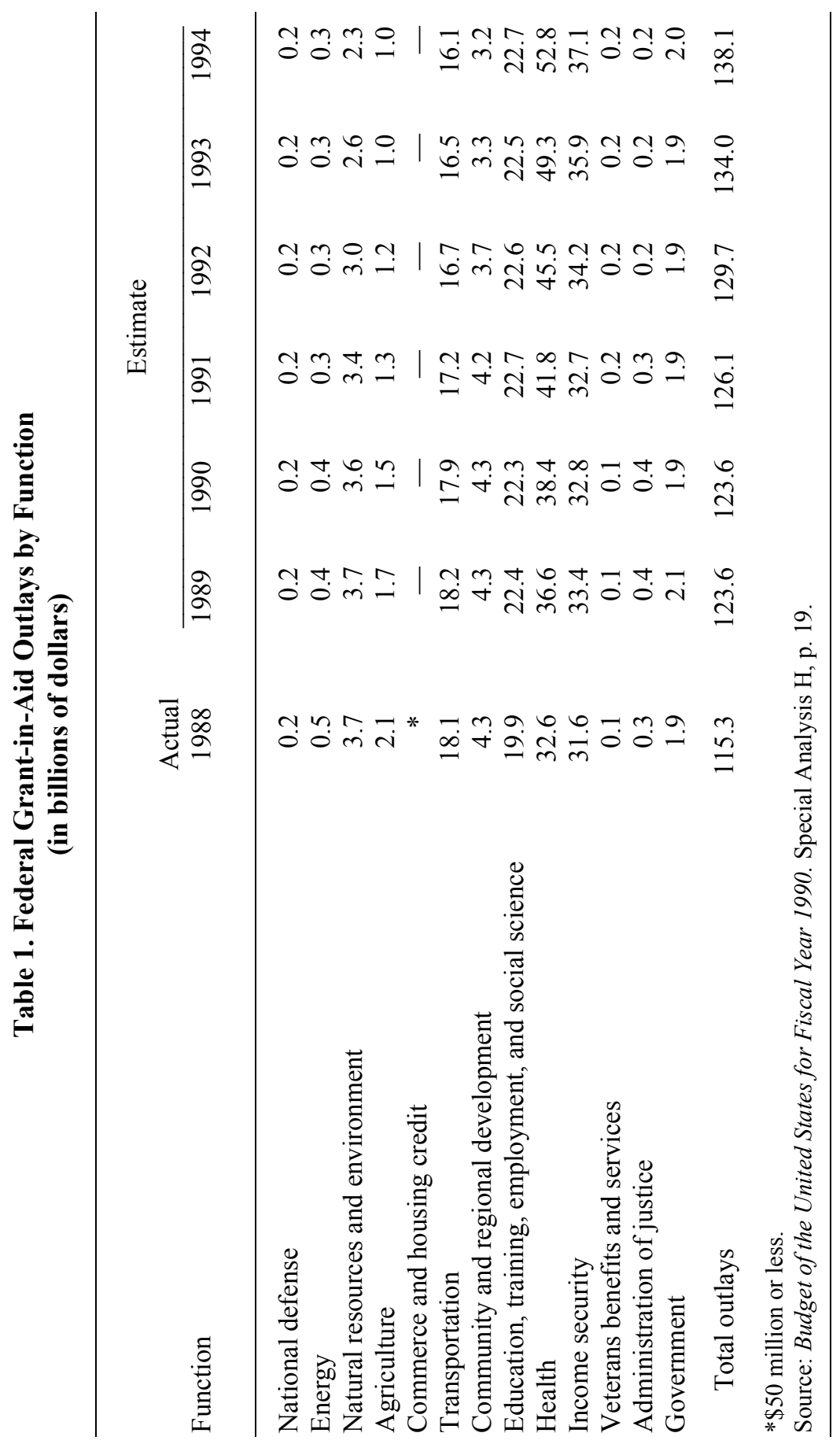


proposes full funding of Head Start, WIC, the National Service Trust Fund (which replaces the student loan program), as well as providing Safe Schools. Clinton's overhaul of the K-12 education system revolves around curricular reform, neighborhood schools, increased standards, testing, and reduced class sizes. Other programs will address the dropout problem (Youth Opportunity Corps), job opportunity for the college-less workforce, (National Apprenticeship Program), and worker retraining.

Specific expenditures by the federal government may be limited in this area. For example, worker retraining will be funded by a 1.5 percent employer payroll contribution, while public programs will be streamlined to clear up confusion and over-bureaucratization and to reduce cost. Many of Clinton's education proposals appear to revolve around the cleanup of existing efforts and greater dependence on family support. Enforcement of higher education standards and full responsibility for the funding of "family workfare" programs may place increasingly heavy burdens on states and on local governments. The billions of dollars slated for lifetime learning could be generated by loan programs, employer-employee contributions, and the redirection of welfare monies.

Social Services. As with the education initiative, many welfare programs will be streamlined and revamped to reflect more of a workfare ethic. Monies generated from "elite" taxes and the collection of unpaid child support will be plugged into the "gap of inequality." Also, the earned income credit expansion, consistent with earlier workfare reforms in the education area, will support working individuals who help themselves. Clinton, though perceived as a welfare liberal by many, advocates workfare and selfhelp, as his initiatives while Governor of Arkansas suggest. Personal improvement through education, training, and "paying what is owed" will reduce federal encumbrances in social services, particularly if the explosion in health care expenditures can be brought under control.

Health Care. Affordable, accessible, quality health care will be the intergovernmental linchpin in the entire Clinton strategy. Deficit reduction, job creation, bureaucratic streamlining, and global competitiveness all may be unreachable goals if health care costs are not addressed in a meaningful manner. Clinton's public endorsement of a national or universal program for basic medical coverage, although popular, will not be phased in until cost reduction measures have taken effect. The Clinton strategy will be to attack medical costs on a broad front - specifically, paperwork reduction methods evolving into universal forms and codes; expanding DRG (Diagnostically Related Groups) restrictions; imposition of equitable treatment practices on the insurance companies; reduction of drug costs; promotion of "managed care" networks; and reduction of bureaucratization in the health care 
industry. Universal coverage, in terms of a core benefits package, will become a "front burner" issue when cost reduction policies bear fruit. Clinton's generational "changing of the guard," given recent meetings between congressional leaders and the President, will not result in a nationalized health care program until later in his administration, if at all. Clinton's agenda probably can be defined best by his public comments during the December, 1992 "Economic Summit" in Little Rock, at which he indicated his concern regarding the problem (Feinsilber 1992, 19A). Medicaid reform may result in a further trimming of enrollees, which could be a major surprise to many who were Clinton devotees during the 1992 campaign.

Justice. As part of the conversion from wartime to a peace-oriented society, Clinton proposes to create a National Police Corps staffed by unemployed veterans and deactivated military personnel. He also proposes to expand community policy (safe neighborhoods), fund more drug treatment, and establish community bootcamps (following Arkansas' example) to discipline first-time, non-violent offenders (Putting People First 1992, 8). The justice proposals coordinate with the "safe schools" initiative and neighborhood redevelopment efforts, while also creating jobs. The promise of federal funding probably hinges upon heavy state and local contributions, as well as private sector partnership.

Natural Resources and Environment. One of the major attributes that $\mathrm{Al}$ Gore brought to the Democratic ticket was his strong record of environmental protection and conservation. Clinton, conversely, had paid substantial lip service to environmentalism, but economic development issues consistently seemed to take precedence during his tenure as Governor of Arkansas. Thus, the proposed "environmental technology system" espoused during the campaign may have to wait until pressing domestic economic issues have been addressed. Funding for expanded environmental programs may depend heavily upon the extent and quality of the economic recovery. The appointment of two former manages of large public utility companies to prominent positions in the administration may reveal the focus of Clinton's environmental effort.

\section{IGR Area Summary}

By deed and by word, President Clinton clarified many of his thoughts concerning intergovernmental relations during the transition period. If the general public inferred from the 1992 election campaign that a new period of substantial intergovernmental expenditures would dawn with Clinton's election, then they will be very much mistaken. On the contrary, the new 
administration appears to be very much concerned about streamlining the IGR bureaucracy and reducing waste. "Putting America to Work" may be more the result of retooling than of new job creation. Workfare, publicprivate partnerships, cost-sharing, individual and corporate responsibility, and increased efficiency appear more representative of Clinton's domestic strategy than runaway expenditures on the federal level.

Winners during the Clinton era in terms of the never-ending bureaucratic competition for resources would appear to be transportation, community and regional development, education and training, justice, and health care. IGR losers, and there will be many, include defense, agriculture, and certain social service programs. "Marginal" priorities in this competition include overall staff cuts in the bureaucracy, environmental protection, universal health coverage, and retiree entitlements. Finally, if Clinton adheres to his "deficit reduction promise," many other desirables could fall prey to the federal hatchet, including especially the promised tax cut for the middle class.

\section{Caveats}

Increased intergovernmental expenditures will be tempered by the nation's $\$ 4$ trillion debt, which for a family of four amounts to $\$ 65,000$. Because interest charges on the debt have grown so high-devouring approximately 40 percent of individual income tax revenues - almost all intergovernmental programs will come under constant fiscal pressures. Debt payments are now the third largest item in the federal budget, and soon will rival military spending, especially if Clinton cuts the military budget.

The debt presents a vicious cycle because if intergovernmental expenditures-especially for infrastructure and education-are not increased, workers will become less productive. And, less productive workers mean a smaller economy, which in turn means smaller paychecks and fewer revenues for government. The basic problem is that the country cannot start to pay off the debt until it quits adding to it. Currently, the debt is growing at a faster rate than is the economy. Thus, to spend more on intergovernmental programs while these growth rates are in such an imbalance just adds to the debt, which will lead to a smaller economy with fewer revenues.

A smaller economy leads to more impoverishment, which in turn expedites increased demands for social services, unemployment insurance, and other forms of governmental assistance. Such a cycle leaves less money for infrastructural development to enlarge the economy. Given that the amount of money available is not likely to increase significantly, one can expect to see President Clinton redirect intergovernmental expenditures from social 
services to infrastructural development - much as he redirected expenditures from social services to education, hospital assistance, and combatting infant mortality during the recession years of the early 1980s.

Another factor that must be taken into consideration when speculating about Clinton's future intergovernmental programs is the extent to which he intends to tackle the national debt. If attempts are made to reduce the debt, intergovernmental expenditures will have to be cut. There is broad consensus about what would have to be done to decrease the debt, and, among other actions, intergovernmental expenditures for entitlements such as Medicaid, food stamps, and farm-price supports would have to be cut. (Such entitlements now add up to slightly more than half of the federal budget and 14 percent of the Gross Domestic Product.) Consensus also exists regarding the necessity of cutting discretionary spending in areas such as housing, transportation, energy, and education-although admittedly the savings would be relatively small.

Reducing the debt at the expense of some intergovernmental expenditures, however, could be counterproductive since the size of the debt, as Steven Mufson $(1992,7)$ maintains, has less of an impact when the government spends on items that would make the economy stronger. In the past, the federal government has been spending fewer and fewer real dollars on investments in the future economy - education, training, roads, bridges, and most importantly research and development (Mufson 1992, 7). (Since such infrastructures erode slowly, most persons are unaware of the impact that the absence of such investment has on the economy.)

Basically, Clinton has proposed linking increased intergovernmental expenditures with national needs in order to leverage investment for creating jobs, reforming health care, and training workers for the future. He suggests spending over \$20 billion a year for each of the next four years of his presidency to rebuild the public infrastructure. Much of this would be for intergovernmental programs. The additional expenditures would help finance bridges, roads, a high speed intercity rail system, and a nationwide fiber-optic information network. Clinton also wants to allocate an undetermined amount for business tax incentives, including tax credits for investments in new and updated factories and equipment.

These plans, he estimates, would cost $\$ 28.3$ billion in 1993, $\$ 34.6$ billion in 1994, and \$35.4 billion in both 1995 and 1996. Education, training, and aid to the disadvantaged would be increased by $\$ 3.5$ billion in 1993, $\$ 5.5$ billion in 1994, $\$ 6.5$ billion in 1995, and $\$ 7$ billion in 1996. In addition, a substantial but as yet unspecified amount of money would be spent on improving the environment, social services, and law enforcement (Congressional Quarterly 1992). These proposed expenditures indicate the 
direction and magnitude of Clinton's commitment to intergovernmental programs.

\section{Intergovernmental Revenue Baselines}

As Figure 1 illustrates, intergovernmental revenues have been increasing steadily in constant (1987) dollars since the early 1980s. After that year, broadbased federal aid once again increased significantly.

Figure 1, however, obfuscates the fact that most of the federal intergovernmental revenues have not increased drastically since the early 1980s. Figure 2 shows that in constant dollars, public welfare programsand to a lesser extent education-received the most substantial increases. Other programs, primarily infrastructural programs, have received little if any increase in federal intergovernmental funds since 1982. The infrastructure, as Clinton repeatedly has pointed out, has been underfunded compared to public welfare and education.

The federal intergovernmental categories used in Figure 2 are defined as follows:

Public Welfare includes cash assistance, vendor payments, payments to other governments for welfare purposes, support for public and private welfare agencies, health and hospital services funded directly by government hospitals and health care agencies, and funds for federal Medicaid, except for money spent by state hospitals (which is reported under the health and hospital category). This category excludes pensions and other benefits for former employees.

Education includes funds for college and other educational institutions, such as those for the blind, deaf, and other handicapped persons. It also includes money for adult and veteran educational programs and direct payments for administrative services, tuition grants, fellowships, aid to private schools, construction of school buildings, and purchase and operation of school buses.

Highways includes money for construction, maintenance, and operation of highways, streets, bridges, tunnels, ferries, street lighting, and snow and ice removal. This category does not include policing and traffic control.

Health and Hospitals includes, under health, funds for health research and education, treatment and immunization clinics, nursing, environmental health, air and water pollution, some ambulance services, and mosquito abatement. It also includes, under hospitals, financing, construction, acquisition, maintenance, and operation of public and private hospital facilities. Money from federal Medicaid for state hospitals also is included. 
Figure 1. Intergovernmental Revenues (in constant dollars)

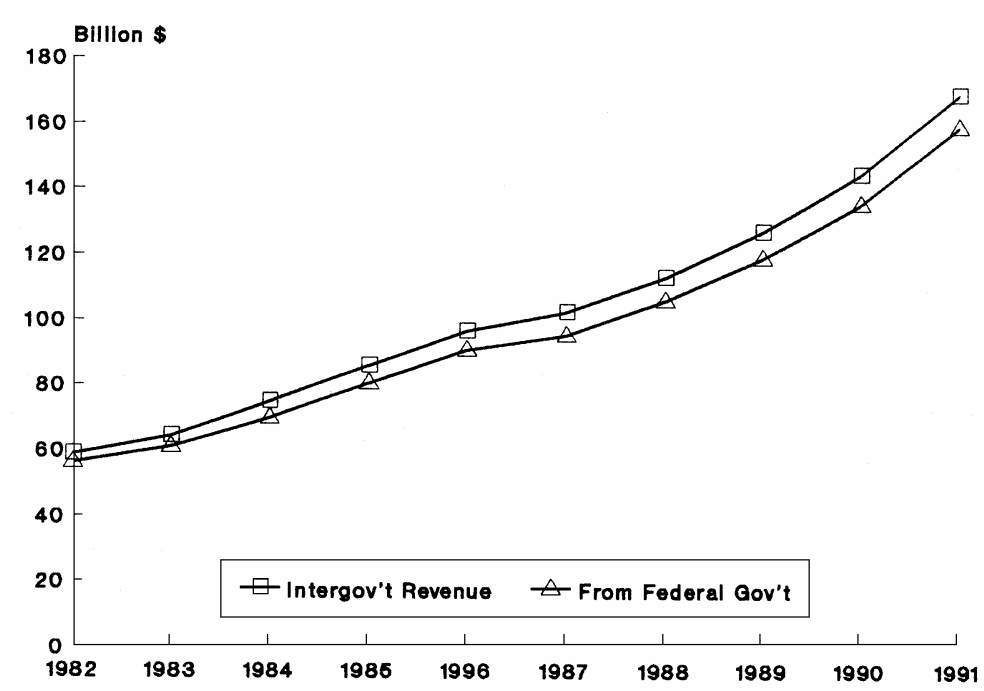

Figure 2. Federal Intergovernmental Revenues by Type (in constant dollars)

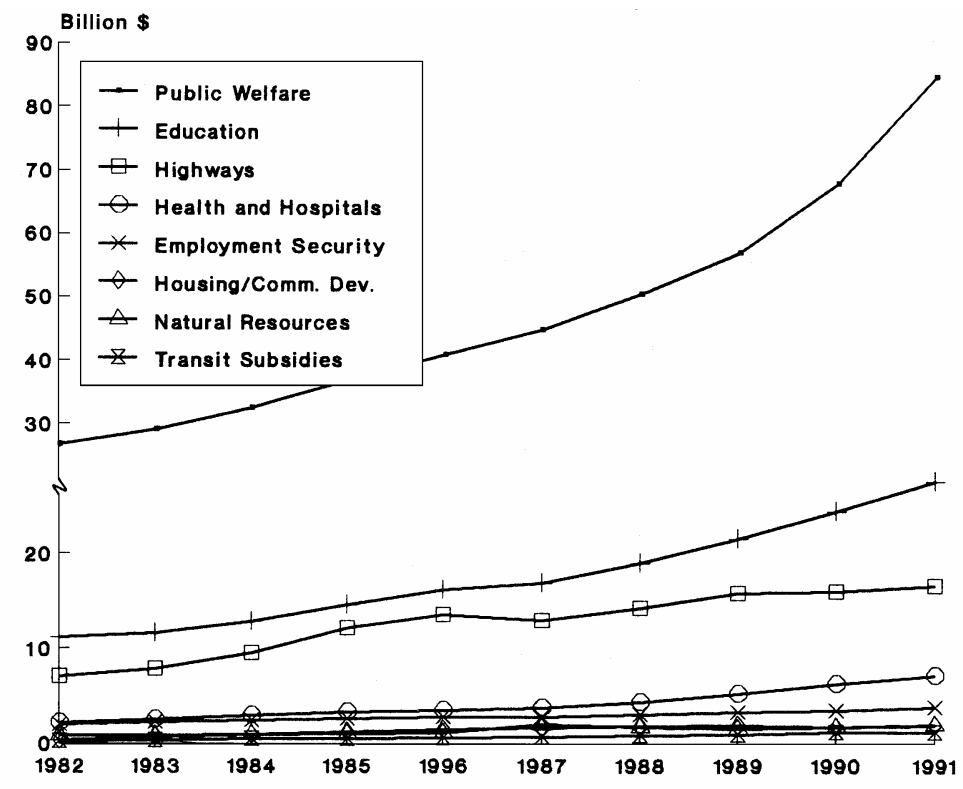


Employment Security Administration includes money for unemployment compensation, public employment offices, and veterans' readjustment allowances.

Housing and Community Development includes money for construction and operation of housing and redevelopment projects.

Natural Resources includes financial support for conservation and for promotion and development of soil, water, forests, minerals, and wildlife. It also includes funds for irrigation, drainage, flood control, forestry, and fire protection, soil and water reclamation and conservation, fish and game programs, and various agricultural projects.

Transit includes money for construction, maintenance, and operation of bus, commuter rail, light rail, and subway systems. It excludes funds for the transportation of public school students and ferry systems.

To speculate on the extent of the Clinton administration's commitment to spending more money on the infrastructure and education systems in states, one needs first to estimate the amount of federal money that probably would have been spent in 1994 and 1995 if Clinton does not intercede to increase or decrease federal intergovernmental revenues. Based on logarithmic regression, Tables 2 and 3 reveal the estimated amount of money that probably would be spent if Clinton does not intermediate with Congress to increase the amount of federal aid to the states.

Based on these estimates, given Clinton's beliefs, opinions, and statements, one can expect significant increases in federal aid to states in the areas of infrastructural development, particularly aid for highways, housing and community development, and natural resources. These areas probably will be targeted for the simple reason that if more federal aid is not forthcoming, less money will be spent in these areas in both 1994 and 1995 than was spent in the early 1990s under President Bush. Thus, this trend in federal intergovernmental expenditures must be altered if President Clinton and his advisors are to hold to their beliefs and statements.

\section{Analysis}

The rhetoric of the 1992 campaign suggested all sorts of promises concerning everything from job creation to cuts in bureaucratic waste. Political realities and actual study of the Clinton-Gore campaign materials indicate quite a different story. Clinton's campaign verbiage suggested, if anything, the Federal Government as a Servant approach to intergovernmentalism. The materials and data reviewed in this analysis, however, intimate a different reality, one consistent with Elazar's National Uniformity model. 
Table 2. Intergovernmental Revenue Estimates by Type, 1994 (in billions of dollars-current)

\begin{tabular}{lcccc}
\hline Type & $\begin{array}{c}1991 \\
\text { Revenues }\end{array}$ & $\begin{array}{c}1994 \\
\text { Estimate }\end{array}$ & $\begin{array}{c}\text { Lower } \\
\text { Limit }\end{array}$ & $\begin{array}{c}\text { Upper } \\
\text { Limit }\end{array}$ \\
\hline Public Welfare & $\$ 71.96$ & $\$ 96.08$ & $\$ 92.63$ & $\$ 99.53$ \\
Education & 23.34 & 29.29 & 28.91 & 29.88 \\
Highways & 14.10 & 11.72 & 10.66 & 12.77 \\
Health \& Hospitals & 6.07 & 8.20 & 8.03 & 8.38 \\
Employment Security & 3.24 & 3.41 & 3.32 & 3.50 \\
Housing \& Community & & & & \\
$\quad$ Development & 1.58 & .799 & .690 & .908 \\
Natural Resources & 1.66 & 1.55 & 1.15 & 1.95 \\
Transit Subsidies & 1.05 & 1.32 & 1.24 & 1.40 \\
& & & & \\
\hline
\end{tabular}

Table 3. Intergovernmental Revenue Estimates by Type, 1995 (in billions of dollars-current)

\begin{tabular}{lrrrr}
\hline Type & $\begin{array}{c}1991 \\
\text { Revenues }\end{array}$ & $\begin{array}{c}1995 \\
\text { Estimate }\end{array}$ & $\begin{array}{r}\text { Lower } \\
\text { Limit }\end{array}$ & $\begin{array}{r}\text { Upper } \\
\text { Limit }\end{array}$ \\
\hline Public Welfare & $\$ 71.96$ & $\$ 106.90$ & $\$ 103.40$ & $\$ 110.30$ \\
Education & 23.34 & 31.68 & 31.10 & 32.26 \\
Highways & 14.10 & 10.53 & 9.67 & 11.59 \\
Health \& Hospitals & 6.07 & 9.06 & 8.88 & 9.23 \\
Employment Security & 3.24 & 3.49 & 3.40 & 3.58 \\
Housing \& Community & & & & .326 \\
$\quad$ Development & 1.58 & .435 & 1.10 & 1.89 \\
Natural Resources & 1.66 & 1.50 & 1.32 & 1.48 \\
Transit Subsidies & 1.05 & 1.40 & & \\
\hline
\end{tabular}

Hard choices face Clinton as he takes office but, like Roosevelt's, his intergovernmental agenda for the first term seems to be directed toward a small, manageable number of priorities: (1) elimination of waste in various IGR programs (e.g., Medicaid) and the reform of entitlements to reflect the administration's workfare agenda; (2) overhaul of the existing health care network to reduce balkanization and paperwork and, ultimately, to reduce 
debt service as a significant negative for future intergovernmental policies; and (3) creation of jobs to rebuild the nation's crumbling infrastructure and to rehabilitate neighborhoods through significant physical rebuilding and social reform.

Superficially, Clinton's IGR agenda appears overwhelmingly amorphous and expensive. Upon deeper reflection, the plan is much narrower in scope and more dependent upon reinvesting federal reform dollars derived from waste management, gaining state and local financial assistance through matching requirements, and expansion of private sector contributions (e.g., training, housing rehabilitation) to create meaningful public-private partnerships (JTPA, Enterprise Zones) to address recurring socioeconomic problems.

\section{Conclusions}

Projecting the future of intergovernmentalism is a speculative enterprise, at best. Nonetheless, Clinton believes he has a mandate for change. To that end, Clinton's policy focus has been (and is being) fine-tuned. Balancing the federal budget is not a short-term, painless process, and states, local governments, and the private sector will be required to become part of the solution instead of part of the problem. Individual determination and self-reliance will be reintroduced in government, and congressional gridlock, which survives the end of divided government, will require moderation if any of the administrative package is to become law.

Elazar's National Uniformity model emphasizes more federal oversight, but does not speak to the issue of where revenues are spent. Clinton's plan is to be financed by controlling waste, cutting some programs, taxing the wealthy, requiring more intergovernmental matching funds and urging private contributions. While Clinton personally would like to spend substantial sums for redevelopment, political realities and his chief advisors force him to choose a more conservative approach.

Still, intergovernmentalism is bound to change in certain regards, given the conditions of (1) a newly elected Democratic, albeit Southern, administration; and (2) ongoing reevaluation of America's security needs and foreign commitments in the post-Soviet era. It is safe to say that several traditional IGR citadels will encounter rare retrenchments, a few new, historically-overlooked areas of activity will receive significant attention, and most of the rest shall have to compete fiercely just to stay in place, given the context of the national debt, the public concern it inspires, and the decade-long record of cautious political economy compiled since the 1980 electoral repudiation of the otherwise liberally-inclined Clinton. An ancient 
Chinese greeting offers, "may you live in interesting times." We suspect that these words, and their implicit curse, speak to what lies ahead for the American agenda during the waning days of the twentieth century.

\section{REFERENCES}

Budget of the United States for Fiscal 1990, Special Analysis H. n.d. Washington, DC: U.S. Government Printing Office.

Clinton, Bill. 1992. Putting People First: A National Economic Strategy for America. Little Rock, AR: The Clinton for President Committee.

Elazar, Daniel. 1972. Fiscal Questions and Political Answers in Intergovernmental Finance. Public Administration Review 32: 471-478.

Feinsilber, Mike. 1992. Little Rock Summit Provides More Than A Glimpse at Clinton's Agenda. Arkansas Democrat-Gazette 12 December 1992.

Kaus, Mickey. 1992. Paradigm's Loss. The New Republic 22 July 1992.

McLarty, Thomas ("Mack") F. 1992. Personal Interview, 28 July 1992 (with R.L. Veasey).

Mufson, Steven. 1992. Mortgage on America. The Washington Post National Weekly Edition 5-11 October 1992.

Veasey, R. Lawson. 1988. Devolutionary Federalism and Elazar's Typology: The Arkansas Response to Reagan's New Federalism. Publius 18: 61-77. 
